\title{
Penerapan Model Pembelajaran Problem Based Learning (PBL) untuk Meningkatkan Prestasi Belajar Siswa
}

\author{
Implementation of Problem Based Learning Model \\ to Improve Student Achievement
}

\author{
Ewo Rahmat \\ SMA Mutiara 2, Bandung, Jawa Barat, Indonesia \\ rahmatewo@gmail.com \\ Naskah diterima tanggal 6/8/2018, Direvisi akhir tanggal 14/7/2018, disetujui tanggal 15/8/2018
}

\begin{abstract}
Abstrak
Penelitian ini bertujuan untuk meningkatkan prestasi belajar siswa dalam materi pembangunan ekonomi melalui model pembelajaran problem based learning (PBL). Jenis penelitian yang dilakukan oleh peneliti adalah Penelitian Tindakan Kelas (Classroom Action Research). Penelitian ini dilaksanakan dengan kolaborasi antara peneliti, dengan rekan guru yang bertindak sebagai Observer dan melibatkan partisipasi siswa. Subjek penelitian ini adalah siswa kelasXIIPSSMA Mutiara 2 Bandung tahun pelajaran 2016/2017, yang berjumlah 32 siswa. Teknik pengumpulan data dilakukan melalui kegiatan berupa: (a) observasi, (b) angket sederhana, (c) tes, dan (d) dokumentasi. Prosedur penelitian meliputi tahap: (a) perencanaan tindakan, (b) pelaksanaan tindakan, (c) observasi dan interpretasi, dan (d) analisis dan refleksi. Berdasarkan hasil penelitian, dapat disimpulkan bahwa model ProblemBased Learning dapat meningkatkan prestasi belajar Ekonomi siswa. Hal ini terbukti pada siklus I nilai rata-rata kelas sebesar 73,00. Pada siklus II terjadi peningkatan nilai rata-rata kelas sebesar 77,75. Jumlah siswa yang mencapai batas tuntas pada siklus I sebanyak 32 siswa atau $80 \%$ sedangkan pada siklus II jumlah siswa yang mencapai batas tuntas sebanyak 33 siswa dari 40 siswa atau sebesar $82,50 \%$ dan pada siklus III jumlah siswa yang mencapai batas tuntas sebanyak 37 siswa dari 40 siswa atau sebesar 92,50\% (mengalami peningkatan sebesar 10\%).Dengan demikian dapat disimpulkan bahwa dengan penerapan model ProblemBased Learning dapat meningkatkan prestasi belajar Ekonomi siswa.
\end{abstract}

Kata kunci: model pembeajaran, pembangunanekonomi, prestasi belajar siswa, problem based learning.

Abstract
This study aims to improve student achievement in economic development materials through problem based learning (PBL) model. The type of research conducted by researchers is Classroom Action Research. This research was carried out in collaboration between researchers, with fellow teachers who acted as Observer and involved student participation. The subjects of this study were students of class XI IPS SMA Mutiara 2 Bandung in the 2016/2017 school year, totaling 32 students. Data collection techniques are carried out through activities such as: (a) observation, (b) simple questionnaires, (c) tests, and (d) documentation. The research procedure includes stages: (a) action planning, (b) implementation of action, (c) observation and interpretation, and (d) analysis and reflection. Based on the results of the study, it can be concluded that the Problem Based Learning model can improve student economic learning achievement. This is evident in the first cycle average grade value of 73.00. In the second cycle there is an increase in the average grade value of 77.75. The number of students who reached the threshold in the first cycle as many as 32 students or $80 \%$ while in cycle II the number of students who reached the threshold as many as 33 students from 40 students or $82.50 \%$ and on the third cycle the number of students who reach the threshold as many as 37 students from 40 students or $92.50 \%$ (increased by 10\%). Thus it can be concluded that the application of the Problem Based Learning model can improve student economic learning achievement.

Keywords: economic development, learning model, problem based learning, student learning achievement. 


\section{PENDAHULUAN}

Pembelajaran atau proses belajar mengajar merupakan suatu proses interaksi (hubungan timbal balik) antara guru dan siswa atau pembelajaran beserta unsur-unsur yang ada di dalamnya (Falestin \& Ulfa, 2015). Pembelajaran merupakan bagian dari Pendidikan, yang di dalamnya ditunjang oleh berbagai unsur-unsur pembelajaran antara lain tujuan, materi pelajaran, sarana prasarana, situasi atau kondisi belajar, media pembelajaran, lingkungan belajar, metode pembelajaran, serta evaluasi. Kesemua unsur-unsur pembelajaran tersebut sangat mempengaruhi keberhasilan proses belajar mengajar untuk meningkatkan prestasi belajar siswa (Anwar \& Khairina, 2014).

Proses belajar mengajar dipengaruhi oleh dua faktor. Faktor pertama adalah faktor yang berasal dari dalam dan faktor yang kedua adalah faktor yang berasal dari luar siswa, sedangkan faktor yang berasal dari luar diri siswa salah satunya adalah metode pembelajaran.Penggunaan metode yang tepat sangat mempengaruhi keberhasilan proses pembelajaran. Akan tetapi, kenyataan yang ada saat ini bahwa masih banyak guru yang menggunakan metode ceramah-resitasi dalam proses pembelajarannya (Hakim, Sunarto, \& Totalia, 2016).

Permasalahan yang timbul adalah pendidikan kita masih didominasi oleh pandangan bahwa pengetahuan sebagai perangkat fakta-fakta yang harus dihafal (Maani, 2016; Hendrowati, 2015). Termasuk mata pelajaran Ekonomi. Disisi lain adanya banyak fakta bahwa guru menguasai materi suatu subjek dengan baik tetapi tidak dapat melaksanakan kegiatan pembelajaran dengan baik. Hal itu terjadi karena kegiatan tersebut tidak didasarkan pada model pembelajaran tertentu sehingga hasil belajar yang diperoleh siswa rendah (Istiatutik, 2017).

Proses belajar mengajar di dalam kelas masih berfokus pada guru sebagai sumber utama pengetahuan, dimana ceramah menjadi pilihan utama proses belajar mengajar (Afrizal, 2012; Natalia, Saneba, \& Hasdin, 2012; Sari, Darmadi, \& Saehana, 2012). Seperti halnya di dalam kelas XI IPS1 SMA Mutiara 2 Bandung.Permasalahan intern yang timbul ketika Kegiatan Belajar Mengajar (KBM) berlangsung dapat dipaparkan sebagai berikut: observasi awal yang dilakukan oleh peneliti menunjukkan bahwa minat dan motivasi siswa untuk belajar Ekonomi masih rendah, baik motivasi internal maupun motivasi eksternal. Hal tersebut tampak dalam tingkah laku siswa ketika pelajaran Ekonomiberlangsung.

Terdapat beberapa kelompok siswa yang tidak memperhatikan dan mengacuhkan penjelasan dari guru yang sedang memberikan penjelasan, bahkan siswa cenderung lebih menikmati mengobrol dengan temanteman mereka dibanding memperhatikan penjelasan dari guru yang ada di depan kelas, ada juga yang mengantuk, menopang dagu. Beberapa diantaranya juga mengemukakan bahwa Ekonomi adalah pelajaran yang sulit dan membingungkan sehingga partisipasi dari merekapun juga kurang. Selain itu, ditinjau dari metode pembelajaran, guru masih menerapkan metode pembelajaran ceramah-resitasi. Begitu masuk kelas, guru memberikan sedikit ceramah tentang materi pelajaran yang telah dicatat sebelumnya, kemudian dilanjutkan dengan memberi siswanya beberapa latihan soal atau tugas.

Siswa diminta untuk membuka buku 
catatan dan mengerjakan buku Lembar Kerja, atau menjawab pertanyaan yang diajukan oleh guru. Proses pembelajaran dengan metode konvensional ceramah-resitasi masih belum cukup memberikan kesan yang mendalam pada siswa, karena peran guru dalam menyampaikan materi lebih dominan dibandingkan keaktifan siswa sendiri(Indah, 2015). Guru lebih banyak memberikan penjelasan daripada mencari tahu sejauh mana siswa bisa menerima dan memahami informasi yang disampaikan. Oleh sebab itu, guru harus mempunyai kreativitas tinggi dalam memilih model pembelajaran yang menarik minat siswa. Agar upaya tersebut berhasil maka harus dipilih model pembelajaran yang sesuai dengan situasi dan kondisi siswa serta lingkungan belajar, siswa dapat aktif, interaktif dan kreatif dalam proses pembelajaran.

Pemilihan model pembelajaran yang tepat merupakan manifestasi dari kreatifitas seorang guru agar siswa tidak jenuh atau bosan dalam menerima pelajaran. Pemilihan model pembelajaran yang tepat juga akan memperjelas konsep-konsep yang diberikan kepada siswa senantiasa antusias berfikir dan berperan aktif (Az Zahra \& Widiyanto, 2015). Model pembelajaran yang efektif dapat digunakan guru untuk mentransfer ilmu dengan baik dan benar, baik secara langsung maupun tidak langsung. Model pembelajaran akan efisien jika menghasilkan kemampuan siswa seperti yang diharapkan dalam tujuan dan sesuai dengan target perhitungan dalam segi materi dan waktu. Seorang guru sebaiknya mampu memilih model yang tepat bagi siswa didiknya (Rahayuningsih, 2015).

Pemilihan model pembelajaran haruslah sesuai dengan tujuan pembelajaran yang dirumuskan. Tujuan pembelajaran yang jelas akan memperjelas proses belajar mengajar dalam arti situasi dan kondisi yang harus diperbuat dalam proses belajar mengajar. Kemampuan dan kualifikasi siswa maupun guru berbeda-beda, sehingga pemilihan model pembelajaran yang tepat juga akan mengalami kesukaran karena tujuan yang berhubungan dengan emosi, perasaan, atau sikap dan tujuan yang beraspek afektif sulit dirumuskan dan sukar diukur keberhasilannya (Siswidyawati, 2009). Model pembelajaran yang digunakan guru seharusnya dapat membantu proses analisis siswa.

Salah satu model tersebut adalah model pembelajaran Problem Based Learning (PBL). Diharapkan model PBL lebih efektif bila dibandingkan dengan metode konvensional. Keefektifan model ini adalah siswa lebih aktif dalam berfikir dan memahami materi secara berkelompok dengan melakukan investigasi dan inquiri terhadap permasalahan yang real di sekitarnya sehingga mereka mendapatkan kesan yang mendalam dan lebih bermakna tentang apa yang mereka pelajari (Istiatutik, 2017). Model PBL merupakan salah satu model pembelajaran dimana authenticassesment (penalaran yang nyata atau konkret) dapat diterapkan secara komprehensif, sebab didalamnya terdapat unsur menemukan masalah dan sekaligus memecahkannya (unsur terdapat didalamnya yaitu problem possing atau menemukan permasalahan dan problem solving atau memecahkan masalah) (Indrianawati, 2013).

Tujuan dari PBL untuk menantang siswa mengajukan permasalahan dan juga menyelesaikan masalah yang lebih rumit dari sebelumnya, dapat meningkatkan keaktifan 
siswa dalam mengemukakan pendapatnya, menggalang kerjasama dan kekompakan siswa dalam kelompok, mengembangkan kepemimpinan siswa serta mengembangkan kemampuan pola analisis dan dapat membantu siswa mengembangkan proses nalarnya. Pengajaran berbasis masalah digunakan untuk merangsang berpikir tingkat tinggi dalam situasi berorientasi masalah, termasuk belajar bagaimana belajar. Pengajaran berbasis masalah tidak dapat dilaksanakan jika guru tidak mengembangkan lingkungan kelas yang memungkinkan terjadinya pertukaran ide secara terbuka. Intinya, siswa dihadapkan pada situasi masalah yang otentik dan bermakna yang dapat menantang siswa untuk memecahkannya (Nurhadi, 2004:109).

Model ini cocok diterapkan pada mata pelajaran Ekonomi karena mata pelajaran ini menuntut siswa untuk dapat memiliki keterampilan dalam melakukan pencatatan seperti pencatatan kedalam jurnal, membuat kertas kerja dan sebagainya. Dimana keterampilan tersebut dapat dilatih setahap demi setahap. Berdasarkan latar belakang masalah tersebut di atas, peneliti merasa perlu mengadakan suatu penelitian yang bertujuan memperbaiki prestasi belajar Ekonomi siswa.

Hasil penelitian ini diharapkan dapat menambah dan mengembangkan pengetahuan dalam bidang pendidikan, khususnya dalam pemilihan metode pembelajaran yang tepat. Memberikan kemudahan dalam mempelajari ilmu pengetahuan dan dapat mengimplementasikan dalam bidang yang sesuai. Sebagai motivasi untuk menerapkan pendekatan keterampilan proses dalam pembelajaran untuk menghasilkan output yang berkualitas. Selain itu sebagai media alternatif dalam mengajarkan materi yang lebih menyenangkan dan mudah dipahami oleh siswa. Hasil penelitian ini akan memberikan sumbangan yang banyak dalam rangka perbaikan pembelajaran di dalam kelas, peningkatan kualitas sekolah yang diteliti, dan bagi sekolah-sekolah lain. Menambah pengetahuan dan pengalaman sebagai guru dapat berusaha sejak sekarang untuk belajar menerapkan model atau metode pembelajaran yang tepat.

\section{METODE PENELITIAN}

Metode yang dipakai dalam penelitian ini adalah penelitian tindakan kelas (PTK). Menurut Kusnandar (2008:21), "PTK adalah merupakan suatu kegiatan yang dilakukan oleh guru atau bersama-sama dengan orang lain (kolaborasi) yang bertujuan untuk memperbaiki atau meningkatkan mutu proses pembelajaran di kelasnya". Sedangkan menurut Suharsimi Arikunto (2010:21) mengungkapkan bahwa "PTK merupakan suatu pencermatan terhadap kegiatan pembelajaran berupa sebuah tindakan, yang sengaja dimunculkan dan terjadi dalam sebuah kelas secara bersamaan".

Penelitian ini dilakukan di Sekolah Menengah Atas (SMA) Mutiara 2 Bandung yang beralamat di Jl.Raya Cibeureum No.10 Kota BandungProvinsi Jawa Barat. Pelaksanaan penelitian ini dilakukan secara kolaborasi dengan guru mata pelajaran yang bertindak sebagai Observer. Dalam Penelitian Tindakan Kelas (PTK) ini yang menjadi subjek penelitian adalah siswa kelas XI IPS-1 yang terdiri dari 32 siswa terdiri dari 11 orang laki-laki dan 21 orang perempuan. Dalam penelitian ini, angket yang digunakan adalah jenis angket tertutup dengan bentuk 
ratingscale. Tes yang digunakan adalah soal uraian yang digunakan untuk mengumpulkan data tentang kemampuan awal dan hasil pembelajaran dengan model pembelajaran PBL pada pelajaran Ekonomi.

Di dalam rencana tindakan, penelitian akan dilakukan dalam tiga siklus yaitu siklus I, Siklus II dan siklus III, di mana masingmasing siklus terdiri dari empat tahap, yaitu: perencanaan tindakan, pelaksanaan tindakan, pengamatan atau observasi tindakan, dan refleksi terhadap tindakan. Dalam tahap ini peneliti melakukan hipotesis tindakan, yaitu untuk meningkatkan kualitas proses dan hasil pembelajaran Ekonomi yang ditunjukkan melalui prestasi belajar dengan penerapan model pembelajaran Problem Based Learning. Proses ini dilakukan dengan mengamati aktivitas pembelajaran Problem Based Learning pada pembelajaran Ekonomi yang telah direncanakan. Peneliti mencari kelebihan dan kekurangan dalam penerapan pembelajaran Problem Based Learning ini dalam memperoleh data yang dibutuhkan. Dilakukan dengan menganalisis data yang telah dikumpulkan pada proses sebelumnya sehingga diperoleh kesimpulan tentang keberhasilan maupun kekurangan dari penerapan pembelajaran Problem Based Learning. Hasil kesimpulan tersebut akan digunakan untuk perbaikan pada tindakan berikutnya yang kemudian ditindaklanjuti dengan perbaikan rencana pelaksanaan pembelajaran.

\section{HASIL DAN PEMBAHASAN}

\subsection{Hasil}

Proses penelitian ini dilakukan dalam tiga siklus yang masing-masing siklus terdiri dari 4 tahapan, yaitu: (1) perencanaan tindakan,
(2) pelaksanaan tindakan, (3) observasi dan interpretasi, dan (4) analisis dan refleksi tindakan.

Pelaksanaan tindakan I dilaksanakan seperti yang telah direncanakan, yaitu Oktober 2016 di ruang kelas XI IPS-1 SMA Mutiara 2 Bandung. Pertemuan dilaksanakan selama $2 \times 45$ menit sesuai dengan skenario pembelajaran dan RPP. Materi Ekonomi pada pelaksanaan tindakan I ini adalah pengertian pembangunan ekonomi dan pengertian tujuan pembangunan ekonomi. Pada pertemuan ini, guru mendemonstrasikan materi secara jelas dan membentuk kelompok belajar, siswa diminta untuk kerja kelompok mengerjakan soal latihan yang telah dirancang secara khusus dengan metode Problem Based Learning.

Peneliti melakukan pengamatan proses pembelajaran Ekonomi dengan menggunakan metode Problem Based Learning di kelas XI IPS-1. Peneliti mengambil posisi di dalam kelas, yaitu di belakang para siswa sambil sesekali berkeliling untuk mengamati dengan jelas jalannya pembelajaran sehingga dapat menilai dengan baik. Kemudian siswa diminta untuk bergabung dengan kelompoknya dan mengerjakan soal secara berkelompok yang hasilnya nanti harus dipresentasikan oleh dua kelompok. Ditutup dengan evaluasi akhir dari siklus I agar hasil belajar dari siklus I dapat segera diketahui.

Dari kegiatan tersebut, deskripsi tentang jalannya proses pembelajaran Ekonomi dengan metode Problem Based Learning sudah dijelaskan secara rinci dalam pelaksanaan tindakan. Berdasarkan hasil pengamatan terhadap pelaksanaan proses belajar mengajar Ekonomi, diperoleh gambaran tentang aktivitas siswa selama 
kegiatan belajar mengajar berlangsung, sebagai berikut: Siswa yang betul-betul aktif selama pemberian apersepsi sebesar $50 \%$, sedangkan 50\% lainnya belum dapat memusatkan perhatian pada awal pembelajaran. Siswa yang aktif dalam kelompok selama kegiatan kerja kelompok berlangsung sebesar 95,24\%, sedangkan $4,76 \%$ lainnya tidak membantu dalam kerja kelompok. Hal ini disebabkan karena siswa yang merasa tidak bisa mengerjakan tidak mau ikut berdiskusi karena kurangnya minat dan motivasi dalam diri mereka. Siswa yang aktif dalam mengemukakan pendapat selama pembelajaran Ekonomi berlangsung sebesar $92,86 \%$, sedangkan $7,14 \%$ yang lainnya masih kurang memperhatikan pelajaran dan kurang aktif.Siswa yang aktif dalam mengajukan pertanyaan mengenai pemahaman materi selama pembelajaran Ekonomi berlangsung sebesar 47,62\%, sedangkan $52,38 \%$ yang lainnya masih kurang memperhatikan pelajaran dan kurang memahami materi yang diajarkan.

Berdasarkan hasil pekerjaan siswa dapat diidentifikasi bahwa siswa yang sudah mampu mengerjakan penyusunan laporan laba-rugi dan laporan perubahan modal dan mendapatkan nilai 70 ke atas sebesar $80 \%$, sedangkan $20 \%$ siswa lainnya belum sempurna dalam menyelesaikan soal yang diberikan. Hal ini disebabkan mereka masih kesulitan memahami suatu materi sehingga ada beberapa hal yang perlu diulang kembali. Hasil observasi yang telah dilakukan dapat dilihat bahwa penerapan metode Problem Based Learning mampu meningkatkan prestasi belajar Ekonomi siswa. Hal ini ditunjukkan dengan meningkatnya nilai rata-rata kelas. Sebelum penerapan metode
Problem Based Learning, rata-rata kelas adalah 69,05 namun setelah diterapkannya metode ini, rata-rata kelas menjadi 72,19. Jumlah siswa yang mendapatkan nilai diatas standar ketuntasan 70 sebanyak 23 siswa dari jumlah keseluruhan 32 siswa. Akan tetapi, indikator ketercapaian pada siklus I belum tercapai dari $85 \%$ target yang direncanakan, yaitu baru $72 \%$ siswa yang memperoleh nilai diatas 70 sedangkan $28 \%$ siswa yang lainnya masih belum tuntas.

Penerapan pembelajaran Ekonomi pada siklus II melalui metode Problem Based Learning sebagai berikut: Kegiatan perencanaan tindakan siklus II dilaksanakan pertengahan Oktober 2016 di ruang guru SMA Mutiara 2 Bandung. Peneliti bersama Observer mendiskusikan rancangan tindakan yang akan dilakukan dalam penelitian ini. Peneliti mengungkapkan bahwa berdasarkan hasil analisis dan refleksi dari siklus I masih terdapat beberapa kekurangan, kemudian disepakati pelaksanaan tindakan pada siklus II. Kegiatan pelaksanaan tindakan siklus II dilaksanakan seperti yang telah direncanakan. Pertemuan dilaksanakan selama $2 \times 45$ menit sesuai dengan skenario pembelajaran dan RPP. Pelaksanaan tindakan siklus II hampir sama dengan pelaksanaan tindakan siklus I, hanya pada pelaksanaan tindakan II ini terdapat perbaikan yang masih diperlukan dari tindakan I.

Materi yang disampaikan pada pelaksanaan tindakan II adalah Pola dan tahapan pembangunan ekonomi. Pada pertemuan siklus II guru menjelaskan dan mendemonstrasikan materi dengan jelas dan dibuka kesempatan tanya jawab, kemudian siswa mengerjakan soal secara berkelompok masih dengan metode yang 
diterapkan di Siklus I. Dilaksanakan kegiatan diskusi dan presentasi, kegiatan ini ditambah dengan tanya jawab yang lebih efektif untuk membangun pemahaman siswa, ditutup dengan evaluasi akhir Siklus II. Peneliti mengamati proses pembelajaran Ekonomi dengan menggunakan metode Problem Based Learning di kelas XI IPS-1. Peneliti mengambil posisi di dalam kelas, yaitu di belakang para siswa sambilsesekali berkeliling untuk mengamati dengan jelas jalannya pembelajaran sehingga dapat menilai dengan baik. Kemudian siswa diminta untuk bergabung dengan kelompoknya dan mengerjakan soal secara berkelompok yang hasilnyananti harus dipresentasikan oleh dua kelompok. Ditutup dengan evaluasi akhir dari siklus II agar hasil belajar dari siklus II dapat segera diketahui. Dari kegiatan tersebut, deskripsi tentang jalannya proses pembelajaran Ekonomi dengan metode Problem Based Learning sudah dijelaskan secara rinci dalam pelaksanaan tindakan II.

Berdasarkan hasil observasi terhadap pelaksanaan proses belajar mengajar Ekonomi, diperoleh informasi tentang motivasi dan aktivitas siswa selama kegiatan belajar mengajar berlangsung, yaitu sebagai berikut: Siswa yang betulbetul aktif selama pemberian apersepsi sebesar $83,33 \%$, sedangkan $16,67 \%$ lainnya belum secara optimal dalam persiapan mengikuti pembelajaran. Siswa yang aktif dalam kelompok selama kegiatan kerja kelompok berlangsung sebesar 95,24\%, sedangkan 4,76\% lainnya masih kurang membantu dalam kerja kelompok. Siswa yang aktif dalam mengemukakan pendapat selama pembelajaran Ekonomi berlangsung sebesar $92,86 \%$, sedangkan $7,14 \%$ yang lainnya masih kurang aktif. Siswa yang aktif dalam mengajukan pertanyaan mengenai pemahaman materi selama pembelajaran Ekonomi berlangsung sebesar 80,95\%, sedangkan 19,05\% yang lainnya masih belum sepenuhnya memahami materi Ekonomi. Siswa yang sudah mampu mengerjakan tes dan mendapatkan nilai 70 ke atas sebesar $81 \%$, sedangkan $19 \%$ siswa lainnya belum sempurna dalam menyelesaikan soal yang diberikan. Hal ini disebabkan mereka kurang teliti dalam mengerjakan soal.

Berdasarkan Hasil observasi siklus II yang telah dilakukan dapat dilihat bahwa penerapan metode Problem Based Learning (PBL) dapat meningkatkan hasil belajar dan prestasi belajar Ekonomi siswa pada mata pelajaran Ekonomi. Siswa sudah jelas dan paham mengenai bagaimana penerapan metode Problem Based Learning (PBL) karena siswa mulai terbiasa dengan metode pembelajaran yang digunakan.Hal ini tentu saja menyebabkan pelaksanaan kegiatan belajar mengajar dengan menggunakan metode Problem Based Learning (PBL) menjadi lebih efektif. Rata-rata nilai siswa kelas XI IPS-1 pada siklus II mengalami peningkatan yaitu sebesar 77,19. Sebanyak $81 \%$ atau 26 siswa dinyatakan tuntas, karena pencapaian hasil belajar siswa diatas standar batas tuntas nilai, yaitu 70. Dari hasil refleksi tersebut dapat diketahui bahwa penerapan metode Problem Based Learning (PBL) pada siklus II dinilai telah berhasil dan dianggap sudah memuaskan tetapi ketuntasan belajar masih di bawah 85\% sehingga perlu dilanjutkan lagi ke siklus berikutnya.

Kegiatan pelaksanaan tindakan siklus III dilaksanakan seperti yang telah direncanakan. Pertemuan dilaksanakan selama 2x45 
menit sesuai dengan skenario pembelajaran dan RPP. Pelaksanaan tindakan siklus III hampir sama dengan pelaksanaan tindakan siklus II, hanya pada pelaksanaan tindakan III ini terdapat perbaikan yang masih diperlukan dari tindakan II. Materi yang disampaikan pada pelaksanaan tindakan III adalah Keberhasilan dan kegagalan pembangunan ekonomi Indonesia. Pada pertemuan siklus III guru menjelaskan dan mendemonstrasikan materi dengan jelas dan dibuka kesempatan tanya jawab, kemudian siswa mengerjakan soal secara berkelompok masih dengan metode yang diterapkan di Siklus II. Dilaksanakan kegiatan diskusi dan presentasi, kegiatan ini ditambah dengan tanya jawab yang lebih efektif untuk membangun pemahaman siswa, ditutup dengan evaluasi akhir Siklus III.

Peneliti mengamati proses pembelajaran Ekonomi dengan menggunakan metode Problem Based Learning di kelas XI IPS-1. Peneliti mengambil posisi di dalam kelas, yaitu di belakang para siswa sambil sesekali berkeliling untuk mengamati dengan jelas jalannya pembelajaran sehingga dapat menilai dengan baik. Kemudian siswa diminta untuk bergabung dengan kelompoknya dan mengerjakan soal secara berkelompok yang hasilnya nanti harus dipresentasikan oleh dua kelompok. Ditutup dengan evaluasi akhir dari siklus III agar hasil belajar dari siklus III dapat segera diketahui. Dari kegiatan tersebut, deskripsi tentang jalannya proses pembelajaran Ekonomi dengan metode Problem Based Learning sudah dijelaskan secara rinci dalam pelaksanaan tindakan II.

Berdasarkan hasil observasi terhadap pelaksanaan proses belajar mengajar
Ekonomi, diperoleh informasi tentang motivasi dan aktivitassiswa selama kegiatan belajar mengajar berlangsung, yaitu sebagai berikut: Siswa yang betulbetul aktif selama pemberian apersepsi sebesar $85,60 \%$, sedangkan $14,32 \%$ lainnya belum secara optimal dalam persiapan mengikuti pembelajaran. Siswa yang aktif dalam kelompok selama kegiatan kerja kelompok berlangsung sebesar 97\%, sedangkan 3\% lainnya masih kurang membantu dalam kerja kelompok. Siswa yang aktif dalam mengemukakan pendapat selama pembelajaran Ekonomi berlangsung sebesar 95\%, sedangkan $5 \%$ yang lainnya masih kurang aktif.Siswa yang aktif dalam mengajukan pertanyaan mengenai pemahaman materi selama pembelajaran Ekonomi berlangsung sebesar 85\%, sedangkan $15 \%$ yang lainnya masih belum sepenuhnya memahami materi Ekonomi. Siswa yang sudah mampu mengerjakan tes dan mendapatkannilai 70 ke atas sebesar $88 \%$ atau 28 , sedangkan $12 \%$ atau 4 siswa lainnyabelum sempurna dalam menyelesaikan soal yang diberikan.Hal inidisebabkan mereka kurang teliti dalam mengerjakan soal.

Berdasarkan hasil observasi siklus III yang telah dilakukan dapat dilihat bahwa penerapan metode Problem Based Learning (PBL) dapat meningkatkan hasil belajar dan prestasi belajar Ekonomi siswa pada mata pelajaran Ekonomi. Siswa sudah jelas dan paham mengenai bagaimana penerapan metode Problem Based Learning (PBL) karena siswa mulai terbiasa dengan metode pembelajaran yang digunakan. Hal ini tentu saja menyebabkan pelaksanaan kegiatan 
belajar mengajar dengan menggunakan metode Problem Based Learning (PBL) menjadi lebih efektif. Rata-rata nilai ulangan harian siswa kelas XI IPS-1 pada siklus III mengalami peningkatan yaitu sebesar 78,91. Sebanyak 88\% siswa dinyatakan tuntas, karena pencapaian hasil belajar siswa diatas standar batas tuntas nilai, yaitu 70. Dari hasil refleksi tersebut dapat diketahui bahwa penerapan metode Problem Based Learning (PBL) pada siklus III dinilai telah berhasil dan dianggap sudah memuaskan sehingga tidak perlu dilanjutkan lagi ke siklus berikutnya.

Berdasarkan hasil observasi dan interpretasi tindakan pada siklus II, observer melakukan analisis sebagai berikut: Guru sudah lebih bisa menguasai kelas sehingga ketika mengajar perhatiannya bisa tersebar pada seluruh bagian kelas. Keaktifan siswa dalam mengikuti kegiatan belajar mengajar mengalami peningkatan. Siswa tidak lagi melakukan hal-hal yang tidak perlu dan jauh lebih bersemangat saat diskusi kelompok dan presentasi berlangsung. Tindakan refleksi yang dapat diambil berdasarkan pengamatan dan analisis Hal tersebut dapat dilihat pada tabel 1 .

Tabel 1. Penerapan Model Problem Based Learning

\begin{tabular}{|c|c|c|c|c|}
\hline \multirow[t]{2}{*}{ Aspek yg diteliti } & \multicolumn{3}{|c|}{ Presentase Capaian } & \multirow[t]{2}{*}{ Peningkatan } \\
\hline & Siklus I & Siklus II & Siklus III & \\
\hline 1. Pemberian Masalah & $90 \%$ & $90 \%$ & $95 \%$ & $5 \%$ \\
\hline 2. Pembagian Kelompok & $75 \%$ & $85 \%$ & $90 \%$ & $15 \%$ \\
\hline 3. Pengarahan diskusi kelompok & $80 \%$ & $90 \%$ & $95 \%$ & $15 \%$ \\
\hline 4. Penyelesaian Masalah & $80 \%$ & $90 \%$ & $95 \%$ & $15 \%$ \\
\hline 5. Refleksi atau Evaluasi & $65 \%$ & $86 \%$ & $90 \%$ & $25 \%$ \\
\hline Rata - rata & $77,80 \%$ & $88,60 \%$ & $93,00 \%$ & $15,00 \%$ \\
\hline
\end{tabular}

(Sumber: data primer yang diolah, 2016)

Berdasarkan hasil aktivitas guru pada tabel 1 tersebut di atas, maka dapat terlihat pada tindakan siklus I, aspek pemberian masalah terdapat $90 \%$, aspek pembagian kelompok $75 \%$, aspek pengarahan diskusi kelompok $80 \%$, aspek penyelesaian masalah $80 \%$ dan aspek refleksi atau evaluasi $65 \%$, sedangkan pada Siklus II, aspek pemberian masalah masih sama yaitu 90\%, aspek pembagian kelompok meningkat $10 \%$ menjadi $85 \%$, aspek pengarahan diskusi kelompok meningkat $10 \%$ menjadi $90 \%$, aspek penyelesaian masalah meningkat menjadi $90 \%$ dan aspek refleksi atau evaluasi meningkat 21\% menjadi $86 \%$, dan pada tindakan Siklus III, aspek pemberian masalah meningkat 5\% menjadi 95\%, aspek pembagian kelompok meningkat $5 \%$ menjadi $90 \%$, aspek pengarahan diskusi kelompok meningkat $5 \%$ menjadi $95 \%$, aspek penyelesaian masalah meningkat 5\% menjadi $95 \%$ dan aspek refleksi atau evaluasi meningkat $4 \%$ menjadi $90 \%$, hasil rata-rata meningkat dari siklus I adalah $77,80 \%$, Siklus II meningkat menjadi $88,60 \%$ dan pada silus III menjadi 93,00\%. Hasil data pada tabel tersebut di atas dapat digambarkan pada diagram sebagai berikut: 


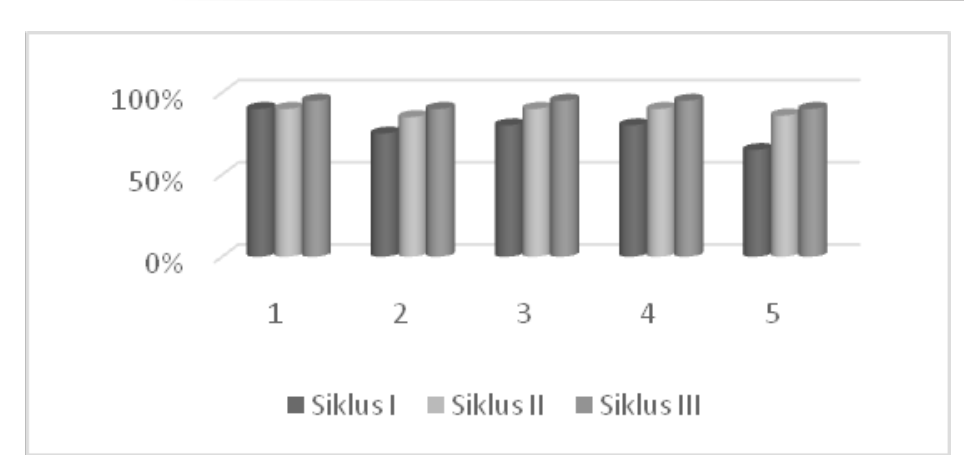

Keterangan:

Gambar 1. Diagram Penerapan Model PBL

1. Pemberian Masalah,

2. Pembagian Kelompok,

3. Pengarahan diskusi kelompok,

4. Penyelesaian Masalah

5. Refleksi atau Evaluasi

Berdasarkan hasil aktivitas guru pada diagram gambar 1 tersebut di atas, maka dapat terlihat pada aspek 1(Pemberian Masalah), siklus I ke siklus II sama hmencapai 90\%, mengalami peningkatan siklus II ke siklus III sebesar 5\% menjadi 95\%, pada aspek 2 (Pembagian Kelompok), siklus I mencapai $75 \%$ pada siklus II meningkat menjadi $85 \%$ pada Siklus II menjadi 90\%, pada aspek
3 (Pengarahan diskusi kelompok) siklus I mencapai 80\%, pada Silkus II mencapai 90\% dan pada siklus III mencapai 95\%. pada aspek 4 (Penyelesaian Masalah) siklus I mencapai $80 \%$, pada Silkus II mencapai $90 \%$ dan pada siklus III mencapai 95\% dan pada aspek 5 (Refleksi atau Evaluasi) siklus Imencapai $65 \%$, pada Silkus II mencapai $86 \%$ dan pada siklus III mencapai 90\%.

Tabel 2. Minat Belajar Siswa

\begin{tabular}{lcccc}
\hline \multirow{2}{*}{ Aspek yang diteliti } & \multicolumn{3}{c}{ Presentase Capaian } & \multirow{2}{*}{ Peningkatan } \\
\cline { 2 - 4 } & Siklus I & Siklus II & Siklus III & \\
\hline 1. Perasaan Senang & $80 \%$ & $90 \%$ & $95 \%$ & $15 \%$ \\
\hline 2. Kemauan & $75 \%$ & $85 \%$ & $90 \%$ & $25 \%$ \\
\hline 3. Kesadaran & $80 \%$ & $80 \%$ & $90 \%$ & $10 \%$ \\
\hline 4. Perhatian & $80 \%$ & $85 \%$ & $85 \%$ & $5 \%$ \\
\hline Rata - rata & $79 \%$ & $86.07 \%$ & $90 \%$ & $14 \%$ \\
\hline
\end{tabular}

(Sumber: data primer yang diolah, 2016)

Berdasarkan hasil minat belajar siswa tabel 2 tersebut di atas,maka dapat terlihat pada tindakan siklus I, aspek perasaan senang terdapat $80 \%$, aspek kemauan $75 \%$, aspek kesadaran $80 \%$, dan aspek perhatian $80 \%$, pada Siklus II, aspek perasaan senang terdapat $90 \%$, aspek kemauan $85 \%$, aspek kesadaran $80 \%$, dan aspek perhatian $85 \%$, da Siklus III, aspek perasaan senang terdapat 95\%, aspek kemauan 90\%, aspek kesadaran $90 \%$, dan aspek perhatian $85 \%$, hasil ratarata meningkat dari siklus I adalah 79\%, Siklus II meningkat menjadi $86,00 \%$ dan pada silus III menjadi 90\%. Hasil data pada tabel 2 tersebut di atas dapat digambarkan pada diagram sebagai berikut: 


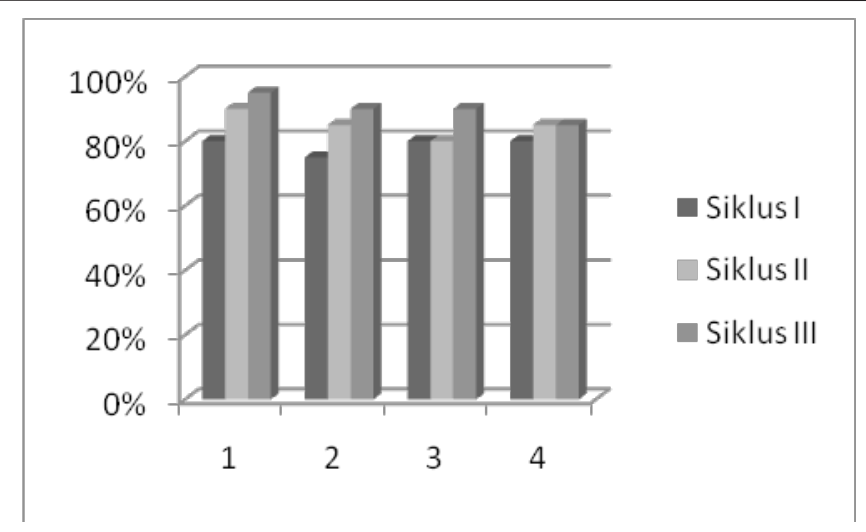

Keterangan:

Gambar 2. Diagram Minat Siswa Dalam Model PBL

\section{Perasaan senang \\ 2. Kemauan \\ 3. Kesadaran \\ 4. Perhatian}

Berdasarkan hasil minat belajar siswa pada diagram gambar 2 tersebut di atas, maka dapat terlihat pada tindakan siklus I, aspek perasaan senang terdapat $80 \%$, aspek kemauan $75 \%$, aspek kesadaran $80 \%$, dan aspek perhatian $80 \%$, pada Siklus II, aspek perasaan senang terdapat 90\%, aspek kemauan 85\%, aspek kesadaran
$80 \%$, dan aspek perhatian $85 \%$, da Siklus III, aspek perasaan senang terdapat 95\%, aspek kemauan 90\%, aspek kesadaran 90\%, dan aspek perhatian $85 \%$, hasil rata-rata meningkat dari siklus I adalah 79\%, Siklus II meningkat menjadi $86,00 \%$ dan pada silus III menjadi $90 \%$.

Tabel 3. Motivasi Belajar Siswa

\begin{tabular}{lcccc}
\hline \multirow{2}{*}{ Aspek yg diteliti } & \multicolumn{3}{c}{ Presentase Capaian } & \multirow{2}{*}{ Peningkatan } \\
\cline { 2 - 4 } & Siklus I & Siklus II & Siklus III & \\
\hline 1. Tekun & $70 \%$ & $90 \%$ & $95 \%$ & $25 \%$ \\
\hline 2. Ulet & $75 \%$ & $80 \%$ & $85 \%$ & $10 \%$ \\
\hline 3. Antusias & $80 \%$ & $85 \%$ & $90 \%$ & $10 \%$ \\
\hline 4. Mandiri & $85 \%$ & $90 \%$ & $95 \%$ & $10 \%$ \\
\hline 5. Kreatif & $85 \%$ & $90 \%$ & $95 \%$ & $10 \%$ \\
\hline $6 . \quad$ Mempertahankan pendapat & $80 \%$ & $90 \%$ & $95 \%$ & $15 \%$ \\
\hline 7. Tidak cepat puas & $90 \%$ & $95 \%$ & $95 \%$ & $5 \%$ \\
\hline 8. Memcahkan masalah & $80 \%$ & $90 \%$ & $95 \%$ & $15 \%$ \\
\hline Rata - rata & $81 \%$ & $89 \%$ & $93 \%$ & $13 \%$ \\
\hline
\end{tabular}

(Sumber: data primer yang diolah, 2016)

Berdasarkan hasil motivasi belajar siswa pada tabel 3 tersebut di atas,maka dapat terlihat pada tindakan siklus I, aspek tekun $70 \%$, ulet $75 \%$, antusias $80 \%$, mandiri $85 \%$, Kreatif $85 \%$, mempertahankan pendapat $80 \%$, tidak cepat puas $90 \%$ dan aspek memcahkan masalah $80 \%$. pada tindakan siklus II, aspek tekun $90 \%$, ulet $80 \%$, antusias $85 \%$, mandiri $90 \%$, Kreatif $90 \%$, mempertahankan pendapat $90 \%$, tidak cepat puas 95\% dan aspek memcahkan masalah 980\%, pada tindakan siklus III, aspek tekun 95\%, ulet $85 \%$, antusias $90 \%$, mandiri $95 \%$, Kreatif $95 \%$, mempertahankan pendapat $95 \%$, tidak cepat puas 95\% dan aspek memcahkan masalah 95\%. Dan ratarata pada siklus I $81 \%$, siklus II $89 \%$ dan pada siklus III 93\%. Hasil data pada tabel tersebut di atas dapat digambarkan pada diagram sebagai berikut: 


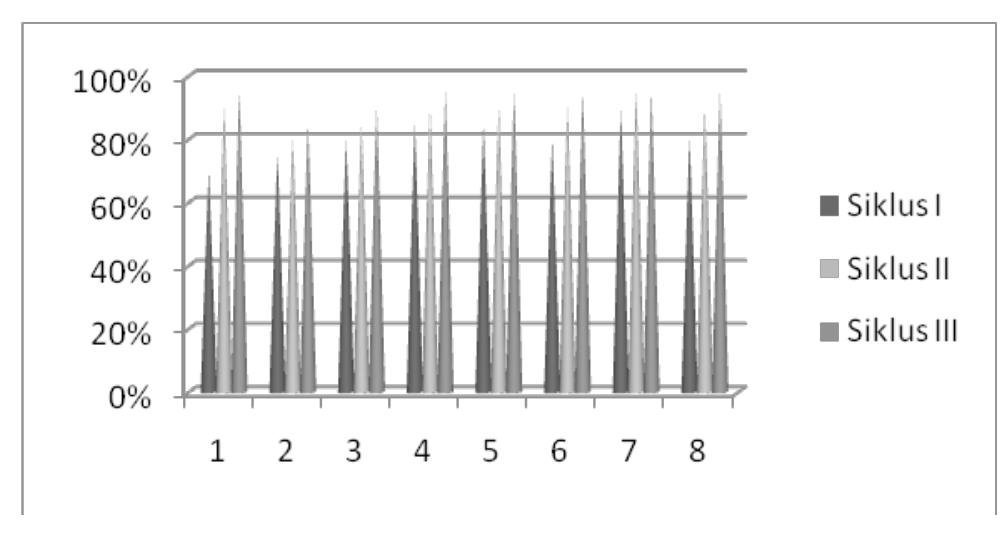

Gambar 3. Diagram Motivasi Belajar Siswa Dalam Model PBL

Keterangan:

1. Tekun

2. Ulet

3. Antusias

4. Mandiri

5. Kreatif

6. Mempertahankan pendapat

7. Tidak cepat puas

8. Memcahkan masalah

Berdasarkan hasil motivasi belajar siswa pada diagram gambar 3 tersebut di atas,maka dapat terlihat pada tindakan siklus I, aspek tekun $70 \%$, ulet $75 \%$, antusias $80 \%$, mandiri 85\%, Kreatif 85\%, mempertahankan pendapat $80 \%$, tidak cepat puas $90 \%$ dan aspek memcahkan masalah $80 \%$. pada tindakan siklus II, aspek tekun $90 \%$, ulet $80 \%$, antusias $85 \%$, mandiri $90 \%$, Kreatif
$90 \%$,mempertahankan pendapat $90 \%$, tidak cepat puas $95 \%$ dan aspek memcahkan masalah 980\%, pada tindakan siklus III, aspek tekun $95 \%$, ulet $85 \%$, antusias $90 \%$, mandiri 95\%, Kreatif 95\%, mempertahankan pendapat $95 \%$, tidak cepat puas $95 \%$ dan aspek memcahkan masalah 95\%. Dan ratarata pada siklus I $81 \%$, siklus II $89 \%$ dan pada siklus III 93\%.

Tabel 4. Partisipasi Belajar Siswa

\begin{tabular}{lcccc}
\hline \multirow{2}{*}{ Aspek yg diteliti } & \multicolumn{3}{c}{ Presentase Capaian } & \multirow{2}{*}{ Peningkatan } \\
\cline { 2 - 4 } & Siklus I & Siklus II & Siklus III & \\
\hline 1. Interaksi dan apersepsi & $70 \%$ & $80 \%$ & $90 \%$ & $20 \%$ \\
\hline 2. Kerjasama dan diskusi kelompok & $80 \%$ & $90 \%$ & $95 \%$ & $15 \%$ \\
\hline 3. Mengemukakan pendapat & $70 \%$ & $80 \%$ & $90 \%$ & $20 \%$ \\
\hline 4. Mengajukan pertanyaan & $60 \%$ & $75 \%$ & $85 \%$ & $25 \%$ \\
\hline 5. Mengerjakan soal/tugas & $80 \%$ & $85 \%$ & $95 \%$ & $15 \%$ \\
\hline Rata - rata & $72 \%$ & $82 \%$ & $91 \%$ & $19 \%$ \\
\hline
\end{tabular}

(Sumber: data primer yang diolah, 2016)

Berdasarkan hasil minat belajar siswa tabel 4 tersebut di atas,maka dapat terlihat pada tindakan siklus I, aspek interaksi dan apersepsi terdapat $70 \%$, aspek kerjasama dan diskusi kelom $80 \%$, aspek mengemukakan pendapat $70 \%$, aspek mengajukan pertanyaan $60 \%$, aspek soal/tugas $80 \%$, pada tindakan siklus II, aspek Interaksi dan apersepsi terdapat $80 \%$, aspek kerjasama dan diskusi kelom $90 \%$, aspek mengemukakan pendapat 
$80 \%$, aspek mengajukan pertanyaan $75 \%$, aspek soal/tugas $85 \%$, pada tindakan siklus III, aspek Interaksi dan apersepsi terdapat $90 \%$, aspek kerjasama dan diskusi kelom $95 \%$, aspek mengemukakan pendapat $90 \%$, aspek mengajukan pertanyaan $85 \%$, dan aspek soal/tugas $95 \%$. Dan rata-rata pada siklus I $72 \%$, siklus II $82 \%$ dan pada siklus III $91 \%$. Hasil data pada tabel tersebut di atas dapat digambarkan pada diagram sebagai berikut:

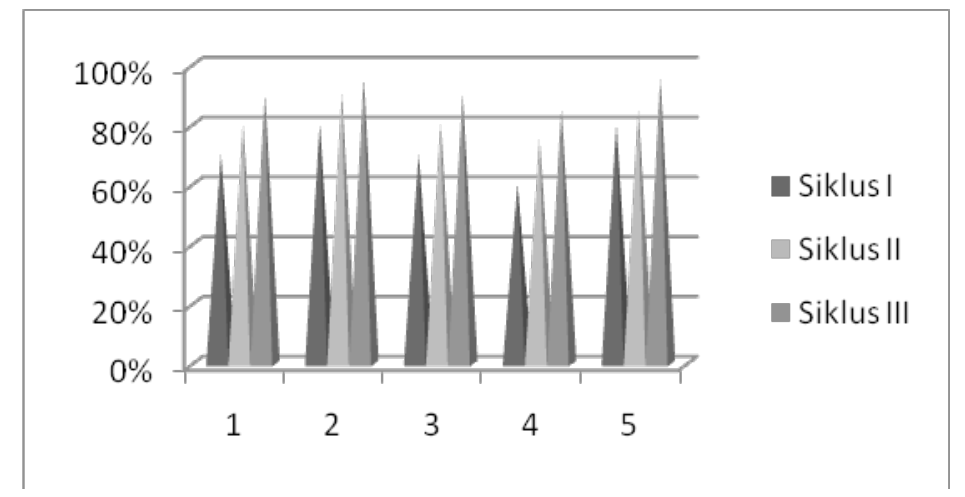

Keterangan:

Gambar 4. Diagram Partisipasi Belajar Siswa Dalam Model PBL

1. Interaksi dan apersepsi

2. Kerjasama dan diskusi kelompok

3. Mengemukakan pendapat

4. Mengajukan pertanyaan

5. Mengerjakan soal/tugas

Berdasarkan hasil minat belajar siswa diagram gambar 4 tersebut di atas,maka dapat terlihat pada tindakan siklus I, aspek interaksi dan apersepsi terdapat $70 \%$, aspek kerjasama dan diskusi kelom 80\%, aspek mengemukakan pendapat $70 \%$, aspek mengajukan pertanyaan $60 \%$, aspek soal/tugas $80 \%$, pada tindakan siklus II, aspek Interaksi dan apersepsi terdapat
$80 \%$, aspek kerjasama dan diskusi kelom $90 \%$, aspek mengemukakan pendapat $80 \%$, aspek mengajukan pertanyaan $75 \%$, aspek soal/tugas $85 \%$, pada tindakan siklus III, aspek Interaksi dan apersepsi terdapat 90\%, aspek kerjasama dan diskusi kelom 95\%, aspek mengemukakan pendapat $90 \%$, aspek mengajukan pertanyaan $85 \%$, dan aspek soal/tugas $95 \%$.

Tabel 5. Ketuntasan Hasil Belajar Siswa

\begin{tabular}{lccc}
\hline \multirow{2}{*}{ Kriteria } & \multicolumn{3}{c}{ Jumlah Capaian } \\
\cline { 2 - 4 } & Siklus I & Siklus II & Siklus III \\
\hline Tuntas & 23 & 26 & 28 \\
\hline Belum Tuntas & 9 & 6 & 4 \\
\hline Jumlah & 32 & 32 & 32 \\
\hline
\end{tabular}

(Sumber: data primer yang diolah, 2016)

Berdasarkan hasil ketuntasan belajar siswa tabel 5 tersebut di atas,maka dapat terlihat pada tindakan siklus I yang telah tuntas ada 23 orang dan yang belum tuntas ada 9 orang dari jumlah 32 orang, pada tidakan siklus II yang telah tuntas ada 26 orang dan yang belum tuntas ada 6 orang dari jumlah 32 orang dan pada siklus III yang telah tuntas 
ada 28 orang dan yang belum tuntas ada 4 tabel tersebut di atas dapat digambarkan pada orang dari jumlah 32 orang. Hasil data pada diagram sebagai berikut:

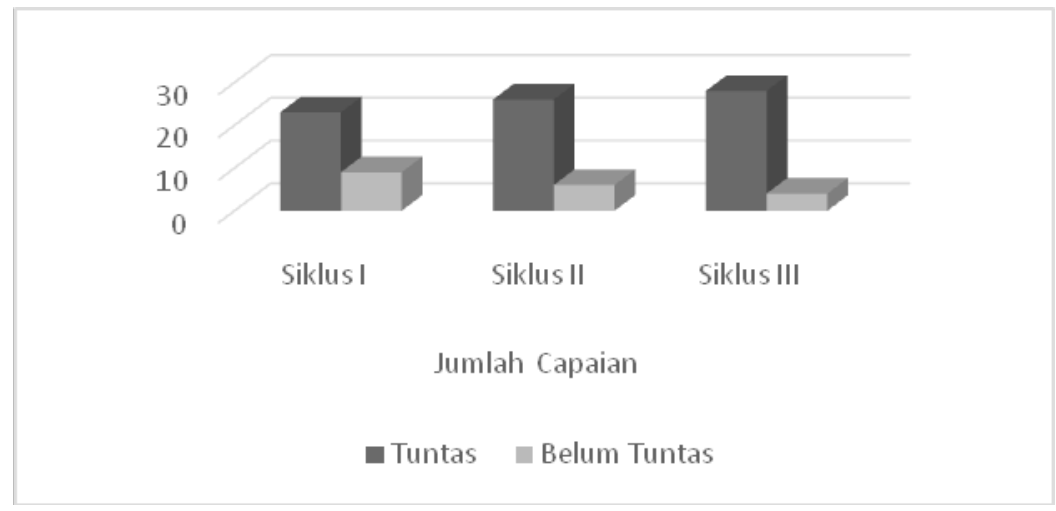

Gambar 5. Diagram Jumlah Siswa yang Tuntas dalam Model PBL

Berdasarkan hasil ketuntasan belajar siswa diagram gambar 5 tersebut di atas, dapat terlihat pada tindakan siklus I yang telah tuntas ada 23 orang dan yang belum tuntas ada 9 orang dari jumlah 32 orang, pada tidakan siklus II yang telah tuntas ada 26 orang dan yang belum tuntas ada 6 orang dari jumlah 32 orang dan pada siklus III yang telah tuntas ada 28 orang dan yang belum tuntas ada 4 orang dari jumlah 32 orang.

\subsection{Pembahasan}

Penerapan model Problem Based Learning (PBL) merupakan penelitian tindakan kelas yang bertujuan untuk meningkatkan prestasi belajar Ekonomi siswa. Penelitian dilakukan dengan menerapkan tiga siklus pembelajaran dengan metode yang sama pada tiap siklusnya, yaitu metode Problem Based Learning (PBL). Penelitian Tindakan Kelas (Classroom Action Research) ini dilaksanakan dalam tiga siklus. Setiap siklus dilaksanakan dalam empat tahap, yaitu: (1) perencanaan tindakan, (2) pelaksanaan tindakan, (3) observasi dan interpretasi, dan (4) analisis dan refleksi tindakan.

Dalam proses pembelajaran di sekolah, pada hakekatnya yang berperan aktif adalah Jurnal Penelitian Pendidikan siswa, sedangkan guru berperan sebagai fasilitator. Dengan demikian, metode mengajar seharusnya beralih dari lecturbased format menjadi studentactiveapproach atau student-centered instruction. Salah satu bentuk pembelajaran yang menerapkan student-active approach atau studentcentered instruction adalah model Problem Based Learning. Dengan adanya penerapan ProblemBased Learning yang merupakan model pembelajaran inovatif, peran guru sebagai pendidik harus bisa membangkitkan minat belajar siswa, motivasi belajar dan partisipasi siswa dalam proses pembelajaran sehingga prestasi belajar siswa akan mengalami peningkatan dibandingkan dengan sebelumnya yang masih menerapkan metode konvensional ceramah.

Nurhadi dalam Trianto

(2009:96) mengemukakan bahwa "Model pembelajaran Problem Based Learning merupakan model pembelajaran yang melibatkan siswa dengan masalah nyata yang sesuai minat dan perhatiannya yang memberdayakan daya fikir, kreativitas, dan partisipasi siswa dalam pembelajaran sehingga motivasi dan rasa ingin tahu menjadi meningkat". Oleh karena itu, siswa diharapkan dapat mengembangkan 
cara berfikir dan keterampilan yang lebih tinggi.

Penerapan model Problem Based Learning menghadapkan siswa pada suatu permasalahan sehingga mereka termotivasi untuk mencari jawaban dengan cara berulang-ulang memecahkan masalah yang dihadapinya yang pada akhirnya dapat menyelesaikan masalah tersebut sehingga dapat meningkatkan rasa percaya diri siswa akan kemampuannya. Peningkatan rasa percaya diri siswa akan kemampuannya dapat membuat siswa menjadi lebih aktif dan berpartisipatif dalam proses pembelajaran karena siswa merasa tertantang untuk menyelesaikan setiap tugas yang diberikan oleh guru dan membuat siswa menjadi lebih yakin dapat meraih prestasi belajar Ekonomiyang lebih tinggi daripada pencapaian sebelumnya.

Hal ini terbukti pada pencapaian prestasi belajar siswa yang mengalami peningkatan sebesar 28\% (prestasi belajar siswa pada siklus I sebesar $72 \%$ atau sebanyak 23 siswa yang tuntas sedangkan pada siklus II mengalami peningkatan menjadi 81\% atau sebanyak 26 siswa dan pada siklus III mengalami peningkatan menjadi $88 \%$ atau sebanyak 28 siswa yang telah tuntas belajar. Berdasarkan tindakan tersebut, guru dan peneliti berhasil melaksanakan pembelajaran Ekonomi yang menyenangkan sehingga prestasi belajar Ekonomi dapat meningkat. Selain itu, dapat meningkatkan kinerja guru dalam melaksanakan pembelajaran yang efektif dan menarik.

\section{KESIMPULAN}

Model Problem Based Learning (PBL) pada penelitian ini telah dilakukan dalam tiga siklus. Tiap siklus dilaksanakan dalam 3 kali pertemuan, dimana pertemuan berlangsung selama 4x45 menit. Secara keseluruhan penerapan model Problem Based Learning telah dapat meningkatkan prestasi belajar siswa. Hal ini terbukti dari pencapaian nilai rata-rata siswa dan jumlah siswa yang mencapai batas ketuntasan. Pada siklus I nilai rata-rata kelas sebesar 72,19 terjadi peningkatan nilai rata-rata kelas sebesar 3,14 dari sebelum diadakannya tindakan yaitu 69,05. Pada siklus II terjadi peningkatan nilai rata-rata kelas sebesar 77,19 (pada siklus I sebesar $72 \%$ menjadi $81 \%$ pada siklus II). Jumlah siswa yang mencapai batas tuntas pada siklus I sebanyak 23 siswa atau $72 \%$, sedangkan pada siklus II jumlah siswa yang mencapai batas tuntas sebanyak 26 siswa dari 32 siswa atau sebesar $81 \%$, dan pada siklus III jumlah siswa yang mencapai batas tuntas sebanyak 28 siswa dari 32 siswa atau sebesar 88\% (mengalami peningkatan sebesar 7\%).

Penerapan model Problem Based Learning secara rinci dapat meningkatkan minat belajar, motivasi belajar dan partisipasi belajar siswa dalam pembelajaran. Siswa diajak untuk turut serta dalam semua proses pembelajaran. Dengan variasi pembelajaran yang terdiri dari diskusi kelompok, pemecahan masalah, dan presentasi membuat siswa merasakan suasana belajar yang lebih menyenangkan dan materi yang disajikan dalam bentuk masalah yang harus dipecahkan menjadi lebih mudah dipahami siswa sehingga dapat meningkatkan minat, motivasi, serta partisipasi siswa. 


\section{DAFTAR PUSTAKA}

Afrizal, R. (2012). Pmbelajaran Bahasa Indonesia Melalui Pendekatan Contextual Teaching And Learning. Jurnal Ilmiah Program Studi Pendidikan Bahasa Dan Sastra Indonesia SEMATIK, 1(6), 76-86.

Anwar, K., \& Khairina, S. L. (2014). Meningkatkan Hasil Belajar Siswa Melalui Model Pembelajaran Problem Based Learning Pada Pelajaran Ipa Materi Pokok Zat Dan Wujudnya Di Kelas IV SD Negeri 064977 Bhayangkara T.P. 2013/2014. Jurnal Pendidikan , 1(1), 164-181.

Arikunto, S. (2010). Prosedur Penelitian Suatu Pendekatan Praktik. Jakarta: Rineka Cipta.

Az Zahra, S., \& Widiyanto. (2015). Analisis Deskriptif Dalam Penerapan Model Pembelajaran PBL (Problem Based Learning) Oleh Guru Mata Pelajaran Ekonomi SMA Negeri 1 Sliyeg Kabupaten Indramayu. Economic Education Analysis Journal, 4(2), 586-602.

Falestin, Y., \& Ulfa, L. F. (2015). Peningkatan Prestasi Belajar Akuntansi Melalui Penerapan Model Pembelajaran Problem Based Learning Pada Siswa Kelas XI IPS 2 SMA Negeri 6 Surakarta. In Pengembangan Pendidikan Akuntansi dan Keuangan yang Berkelanjutan (pp. 192-207).

Hakim, M. A. A., Sunarto, \& Totalia, S. A. (2016). Penerapan Model Pembelajaran Problem Based Learning (Pbl) Untuk Meningkatkan Hasil Belajar Peserta Didik Kelas Xi Iis Dalam Mata Pelajaran Ekonomi Di Sma N 5 Surakarta Tahun Ajaran 2015/2016. Universitas Sebelas Maret.

Hendrowati, T. Y. (2015). Pembentukan Pengetahuan Lingkaran Melalui Pembelajaran Asimilasi Dan Akomodasi Teori Konstruktivisme Piaget. Jurnal E-DuMath , 1(1), 1-16.

Indah, N. (2015). Meningkatkan Prestasi Belajar Ipa Materi Pokok Sumber Energi Gerak Melalui Penerapan Model Pembelajaran Problem Based Learning (PBL) Pada Siswa Kelas I.A SD Negeri 9 Kabangka Tahun Ajaran 2014/2015. Indoensian Journal of Education and Learning, 2(3), 50-55.

Indrianawati, I. (2013). Studi Komparasi Hasil Belajar Siswa Menggunakan Model PBL DAN Model Pembelajaran Kooperatif Tipe STAD. Universitas Negeri Surabaya.

Istiatutik. (2017). Penerapan Metode Problem Based Learning untuk Meningkatkan Hasil Belajar Pelajaran Ekonomi. Jurnal Pendidikan Riset \& Konseptual, 1(1), 45-51.

Kusnandar. (2008). Langkah Mudah Penelitian Tindakan. Jakarta: Rajawali Press.

Maani, S. (2016). Penerapan Problem Based Learning Terhadap Prestasi Belajar Siswa Kelas XII SMA Muhammadiyah Bolo Tahun Pelajaran 2015/2016. Jurnal Pendidikan Mandala JUPE, 1(1), 178-189.

Natalia, A., Saneba, B., \& Hasdin. (2012). Penerapan Pembelajaran Berbasis Portofolio Untuk Meningkatkan Hasil Belajar IPS Siswa Kelas IV SD Inpres 1 Slametharjo Kabupaten Banggai. Jurnal Kreatif Tadulako Online, 5(1), 30-44.

Nurhadi. (2004). Kurikulum 2004 : Pertanyaan dan Jawaban. Jakarta: Grasindo.

Rahayuningsih, M. (2015). Peningkatan Motivasi Dan Hasil Belajar Akuntansi Jasadengan Pembelajaran Problem Based Learning. Indoensian Journal of Education and Learning, 1(2), 43-51.

Sari, N., Darmadi, W., \& Saehana, S. (2012). Perbedaan Hasil Belajar Fisika Antara Siswa Yang Belajar Melalui Model Pembelajaran Discovery Berbantuan Simulasi Komputer Dengan Model Konvensional Di SMA Negeri 7 Palu. Jurnal Pendidikan Fisika Tadulako (JPFT, 3(4), 12-16.

Siswidyawati, N. (2009). IMplikasi Model Problem Based Learning Untuk Meningkatkan Hasil Belajar Siswa Pada Pelajaran Biologi Kelas VII-A SMP Negeri 1 Gesi Tahun Ajaran 2007/2008. Universitas Sebelas Maret. 